\title{
SPATIAL ANALYSIS OF SOCIAL NETWORKING SERVICES IN THE VOLYN REGION
}

\author{
${ }^{1}$ Serhiy PUHACH, ${ }^{2}$ Yulia MYTCHYK \\ 1,2Lesya Ukrainka Eastern European National University, Ukraine \\ 'puhachserhiy@gmail.com
}

\begin{abstract}
Social networking services are one of the distinctive modern phenomena. They are studied by many sciences. However, the spatial aspects of the development and functioning of social networking services are not fully explored. There are some studies in the English-language literature of various geographical aspects of the functioning of social networking services and their integration into GIS. But scientific publications of the geography of social networking services are practically absent in Ukraine. The purpose of this paper is to identify the peculiarities of the spatial differentiation of social networking services in the Volyn region. The main task is to analyze the number of accounts and the structure of users of social networking services VKontakte, Odnoklassniki and Facebook in the context of administrative districts and large cities of Volyn region. As a result of the study, it was revealed that social networks VKontakte, Classmates and Facebook have comparable audiences in the Volyn region. The biggest social networking is VKontakte, the second place belongs to Odnoklassniki, while Facebook is on the third place. Social network VKontakte dominates in the north of the Volyn region, Odnoklassniki - in the south and east. Facebook is the leader only in one administrative unit - Lutsk district. All three networks have similar territorial patterns of user distribution. Two thirds of users are concentrated in the cities of Lutsk, Kovel, Novovolynsk, and Volodymyr-Volynsky. More than $40 \%$ of the accounts are concentrated in Lutsk. The theory of the spatial diffusion of innovations is clearly traceable. The penetration rate of the social networking services is the highest in the largest cities. In Lutsk, it amounts to $76.5 \%$ for social networking service VKontakte, $67.3 \%$ for Odnoklassniki, and $70.1 \%$ for Facebook. In addition to large cities, many users of the social networking services live in the border areas of Lyuboml, Shatsk, Ratne, and Lyubeshiv districts. However, for most districts of the Volyn region, the penetration rate of the network is $10-20 \%$. This indicates a lack of network formation and significant perspectives of further development in rural areas. Women are dominating in sex structure, especially in the Odnoklassniki.
\end{abstract}

Key words: social networking service, VKontakte, Odnoklassniki, Facebook, network penetration.

DOI: https://doi.org/10.17721/2413-7154/2018.79.14-21

UDC: $911.3[316.472 .4: 004.738 .5](477.82)$

Received: April 11, 2018.

Revised: May 24, 2018.

Accepted: May 25, 2018.

\section{ПРОСТОРОВИЙ АНАЛІЗ СОЦІАЛЬНИХ ІНТЕРНЕТ-МЕРЕЖ У ВОЛИНСЬКІЙ ОБЛАСТІ}

\author{
'Сергій ПУГАЧ, Юлія МИТЧИк \\ 1,2Східноєвропейський начіональний університет імені Лесі Українки, Україна \\ 'puhachserhiy@gmail.com
}

Анотація: Соціальні інтернет-мережі $\epsilon$ одним із феноменів сьогодення. Їх вивченням замаються багато наук. Просторові аспекти розвитку та функціонування соціальних інтернет-мереж вивчені не у повній мірі. В англомовній науковій літературі зустрічаються дослідження різних географічних аспектів функціонування соціальних мереж та можливості їх інтеграції в ГІС. Але в Україні наукові публікації з питань географії соціальних мереж практично відсутні. Метою дослідження $\epsilon$ виявлення особливостей просторової диференціації соціальних інтернет-мереж у Волинській області. Головним завданням - на основі аналізу акаунтів дослідити чисельність та структуру користувачів соціальних інтернет-мереж ВКонтакті, Однокласники та Facebook у розрізі адміністративних районів та міст обласного підпорядкування Волинської області. У результаті дослідження виявлено, що соціальні інтернет-мережі ВКонтакті, Однокласники та Facebook мають співставні аудиторії у Волинській області. Найпоширенішою соціальною мережею $\epsilon$ ВКонтакті, на другому місці знаходяться Однокласники, на третьому - Facebook. Соціальна мережа ВКонтакті домінує на півночі Волинської області, Однокласники - на півдні та сході. Facebook переважає лише в одній адміністративній одиниці - Луцькому районі. У всіх трьох мережах простежуються схожі територіальні закономірності поширення. Дві третіх користувачів зосереджені містах Луцьк, Ковель, Нововолинськ, Володимир-Волинський. Понад 40 \% акаунтів концентрує Луцьк. Чітко простежується теорія просторової дифузії нововведень. Коефіцієнт проникнення соціальної мережі також $\epsilon$ найвищим у найбільших містах: у Луцьку він становить 76,5 \% для ВКонтакті, 67,3 \% - для Однокласники, 70,1 \% - для Facebook. Крім великих міст багато користувачів соціальних мереж $\epsilon$ у прикордонних територіях: Любомльському, Шацькому, Ратнівському, Любешівському районах.Для більшості районів Волинської області коефіцієнт проникнення мережі становить 10-20\%, що свідчить про недостатній рівень сформованості мереж та значні перспективи їх розвитку у сільській місцевості. У статевій структурі користувачів домінують жінки, особливо це характерно для мережі Однокласники.

Ключові слова: соціальна інтернет-мережа, ВКонтакті, Однокласники, Facebook, проникнення мережі. 
Вступ. Однією з ознак сучасного глобалізованого світу є зростання ролі комунікацій. Поряд з розвитком та вдосконаленням різних видів транспорту, масовими переміщеннями матеріалів, енергії та інформації, інтенсивними міграційними процесами, значно інтенсифікувалися процеси людського спілкування. Людину охоплює інформаційне поле, яка 3 появою та широким розповсюдженням соціальних інтернетмереж значно розширилося. Великі відстані та державні кордони перестали бути перешкодою для обміну думками між людьми, сферою спілкування став цілий світ. Комунікації людини вийшли на якісно новий рівень, який поки що ще не до кінця осмислений науковцями. Сучасна людина сьогодні перебуває ніби у двох світах: реальному фізичному світі та віртуальному світі соціальних мереж. Наразі, просторові аспекти дослідження соціальних інтернет-мереж в Україні не викликають значного інтересу у дослідників. Саме тому тема дослідження $\epsilon$ надзвичайно актуальною.

Теоретико-методологічні основи дослідження. Дослідження соціальних інтернет-мереж розпочалося у США та країнах Європи. Відповідно, основні напрацювання зосереджені в англомовній науковій літературі, переважно соціологічного напрямку. Низка праць присвячена питанням територіального поширення та просторовим аспектам функціонування соціальних он-лайн сервісів. Так, теоретичним питанням дослідження соціальних мереж 3 позиції економічної та соціальної географії присвячені роботи Ter Wal A., Boschma R. [13] та Glückler J., Doreian P. [4]; вплив відстані на інтенсивність зв'язків в соціальних інтернет-мережах досліджували Lengyel B., Varga A., Ságvári B., Jakobi Á., Kertész J. [6]; аналізу різномасштабних географічних патернів, що виникають внаслідок взаємодії користувачів у соціальних мережах присвячені роботи Menezes T, Roth C. [7] тa Borge-Holthoefer J., Rivero A., García I., Cauhé E., Ferrer A., Ferrer D. та ін. [2]; можливості інтеграції даних соціальних мереж у ГІС вивчали Sui D., Goodchild M. [11] та Andris C. [1]; вплив географічної відстані, національних кордонів, мови та частоти авіаперевезень на формування соціальних зв'язків у Twitter розглядали Takhteyev Y, Gruzd A, Wellman B. [12]; зв'язок між віддаллю та інтенсивністю он-лайн взаємодії на прикладі іспанської соціальної мережі Tuenti вивчали Laniado D., Volkovich Y., Scellato S., Mascolo C., Kaltenbrunner A. [5].

В Україні дослідженнями соціальних мереж також займаються переважно соціологи, аналізуючи сам феномен соціальної інтернет-мережі, аспекти їх впливу на суспільство, окремі його вікові категорії (насамперед дітей та підлітків), можливості використання сервісів у політтехнологіях, освітньовиховному процесі. Періодично в медійному просторі з'являються огляди різноманітних кількісних технічних характеристик мереж, виконаних спеціалістами у сфері IT-технологій. Географічним аспектам у таких дослідженнях, або взагалі не знаходиться місця, або ж ці характеристики

(C) Serhiy Puhach, Yulia Mytchyk дуже поверхневі. Серед досліджень просторових закономірностей поширення соціальних інтернетмереж в Україні насамперед можна згадати комплексне дослідження українців в соціальних мережах, виконане Яндексом [9], та тези доповіді «Географія поширення соціальних мереж в Україні» [10]. Це вказує про незадовільний стан дослідження географічних аспектів розвитку та функціонування соціальних мереж. Публікації по географії соціальних мереж у Волинській області та інших областях України практично відсутні. Це ще раз вказує про недостатній рівень дослідження вказаного питання.

Мета i завдання дослідження. Метою дослідження $є$ виявлення особливостей просторової диференціації соціальних інтернет-мереж у Волинській області. Головним завданням - на основі аналізу акаунтів дослідити чисельність та структуру користувачів соціальних інтернет-мереж ВКонтакті, Однокласники, та Facebook у розрізі адміністративних районів та міст обласного підпорядкування Волинської області.

Опис методики дослідження та здобутих емпіричних даних. Існують певні труднощі із збором первинної статистичної інформації стосовно користувачів соціальних інтернет-мереж. По-перше, акаунти (облікові записи користувачів) - це персональна інформація, розголошувати яку компанія не має права без згоди власника. Прикладом може бути сучасний скандал навколо Facebook, щодо використання персональних даних у політтехнологіях виборів Президента США та Brexit. По-друге, соціальні мережі перетворилися на великі бізнес-проекти доходи яких прямо пропорційні розміру мережі, тому сервіси часто завищують дані про кількість власних користувачів. По-третє, один користувач може мати кілька акаунтів, деякими 3 них він в силу тих чи інших причин мало користується або не використовує зовсім. По-четверте, у соціальних мережах під обліковими записами приховується багато ботів спеціальних програм, які виконують певні дії через інтерфейс, призначений для людей. Виходячи з вище вказаного, говорити можна лише про приблизну кількість користувачів соціальної мережі.

Для визначення кількості користувачів ВКонтакті [16] та Однокласники [8] ми використовували меню «пошук людей» (Пошук Люди - Країна - назва населеного пункту). Було визначено кількість користувачів в усіх 1087 населених пунктах Волинської області. Недоліком такої методики є врахування усіх акаунтів (у т. ч. й тих, якими не користуються).

Mepeжа Facebook [3] не показує кількість акаунтів у населеному пункті за допомогою інструментів пошуку. Для визначення кількості користувачів ми використовували функцію таргетингу - рекламного механізму, завдяки якому можна виділяти з інтернетаудиторії тільки ту частину відвідувачів або цільову аудиторію, яка підходить за певними критеріями. Критерієм ми вибирали охоплення території.

Первинні статистичні дані кількості користувачів соціальних інтернет-мереж в 
окремих населених пунктах Волинської області збиралися в кінці жовтня - на початку листопада 2017 p.

При порівнянні мереж ВКонтакті, Однокласники та Facebook варто наголосити також на та тому, що ВКонтакті та Однокласники показують усі акаунти (навіть неактивні), a Facebook - тільки активні акаунти (місячну аудиторію), тобто ті, якими хоч один раз за останній місяць користувалися. Саме тому у різноманітних звітах та дослідженнях Facebook у нас поступається лідерством ВКонтакті та Однокласники.

Також варто торкнутися етичного моменту дослідження. Нам часто задають питання про законність нашого дослідження, адже соціальні мережі ВКонтакті та Однокласники в Україні знаходяться під забороною. По-перше, керівник служби з питань інформаційної безпеки апарату РНБО України В. Петров заявив, що до українських користувачів не будуть застосовувати будь-які санкції за використання заборонених російських соціальних мереж [15]. Подруге, навіть після блокування українці продовжують активно користуватися цими мережами. Оскільки явище існує, то його варто досліджувати, так само як і злочинність, соціальні негаразди та ін.

Оцінка та обговорення результатів

ВКонтакті $€$ однією із найпопулярніших соціальних інтернет-мереж в Україні. В ній зареєстровано 27,5 млн українських користувачів [16], що становить 64,8 \% населення країни. У Волинській області нараховується 370,3 тис. зареєстрованих користувачів, що становить 35,7 \% населення області та 1,3\% усіх українських користувачів мережі (частка області у населенні країни становить 2,5%). Тобто, рівень проникнення мережі ВКонтакті у Волинській області є значно нижчим, ніж у середньому по Україні. Низьке охоплення аудиторії характерне й для інших соціальних мереж.

Аналізуючи просторовий розподіл користувачів ВКонтакті серед адміністративних районів Волинської області, можна простежити тенденцію до концентрації переважаючої кількості акаунтів у великих містах, а саме у Луцьку (163,7 тис. користувачів), Ковелі (39,4 тис. користувачів), Нововолинську (23,0 тис. користувачів) та Володимир-Волинському (19,6 тис. користувачів). На ці чотири міста обласного підпорядкування припадає 66,6 \% користувачів з Волині. В обласному центрі - м. Луцьк сконцентровано 44,2 \% акаунтів. Такий розподіл пояснюється перш за все охопленням населення глобальною мережею Інтернет. Волинська область має порівняно низький в Україні рівень урбанізації (52,3%). У багатьох селах відсутній не лише Інтернет, а й стійкий сигнал мобільної мережі. Також підтверджується теорія просторової дифузії нововведень Т. Хегерстранда - найбільші міста області виступають своєрідними регіональними центрами інновацій.

Важливим показником, що характеризує поширення сервісу, є рівень проникнення сочіальноі мережі, який обчислюється як відношення кількості акаунтів на певній території до чисельності населення, яке на ній проживає. Цей показник, у першому наближенні, можна вважати, як частку населення зареєстровану у соціальній мережі. Найвищий цей показник у містах обласного підпорядкування (понад $40 \%$ ), особливо вирізняється м. Луцьк - 76,5 \% (рис. 1a).

У адміністративних районах цей показник значно менший i не перевищує 30 \%. Аномально високий показник серед адміністративних районів Волинської області має Шацький район (52,6 \% населення зареєстровано у мережі ВКонтакті). Ця, на перший погляд, парадоксальна ситуація пояснюється наявністю на території району села із назвою Прип’ ять. Фани комп'ютерної гри S.T.A.L.K.E.R. часто місцем проживання вибирають м. Прип'ять, поблизу якого відбулася аварія на ЧАЕС. Оскільки багато геймерів 3 Росії (та й з України) не відзначаються глибокими знаннями 3 географіï, то вони часто вибирають c. Прип'ять Шацького району, яке $є$ першим у випадаючому списку. Так, невелике поліське село iз населенням менше 600 осіб вказане як місце проживання у 6698 користувачів мережі ВКонтакті (переважно із Росіі). Без акаунтів с. Прип'ять, рівень проникнення мережі у Шацькому районі становить $13,0 \%$.

Відносно висока частка користувачів прослідковується у північних прикордонних районах області, а саме Любомльському, Ратнівському та Любешівському. Це пояснюється тісними зв'язками 3 сусідніми державами - Польщею та Білоруссю. Значна частина місцевого населення має родинні зв'язки за кордоном (особливо це характерно для Білорусі), а також здійснює трудові закордонні міграції. Транскордонні комунікації за допомогою соціальних інтернет-мереж $є$ фактично безкоштовними і $є$ альтернативою мобільному зв' язку. Це сприяє збільшенню кількості користувачів на даній території. Висока частка зареєстрованих користувачів спостерігається також у Рожищенському районі, що можливо, можна пояснити його розташуванням між двома найбільшими центрами у Волинській області - містами Луцьк та Ковель, що сприяє підвищенню комунікацій населення.

Найнижча частка користувачів (менше $10 \%$ ) зафіксована у Володимир-Волинському та Луцькому районах. Це пояснюється тим, що жителі сільських населених пунктів часто вважають більш престижним вказувати, як місце проживання найближче велике місто - у нашому випадку Володимир-Волинський та Луцьк. Низький відсоток користувачів характерний також для Іваничівського (13,1 \%) та Ковельського $(11,9 \%)$ районів - територій, прилеглих до міст обласного підпорядкування (Нововолинськ, Ковель).

Для більшості районів Волинської області коефіцієнт проникнення соціальної мережі становить 10-20\%, при середньообласному 35,7 \%. Це ще раз вказує на нерівномірний розподіл користувачів у міських поселеннях та сільській місцевості та ролі великих міст, як центрів інновацій.

Аналіз статевої структури користувачів ВКонтакті у Волинській області вказує на незначне переважання жінок над чоловіками - 50,5 \% проти 49,9\%. 


\section{a) ВКонтакті}

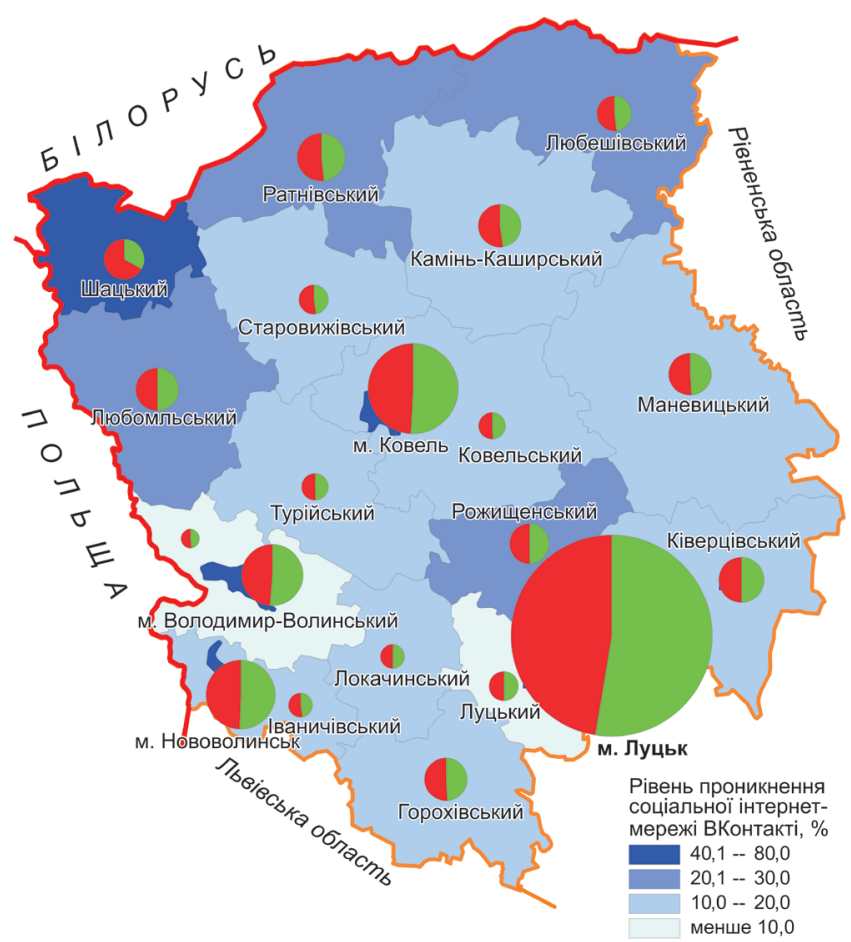

c) Facebook

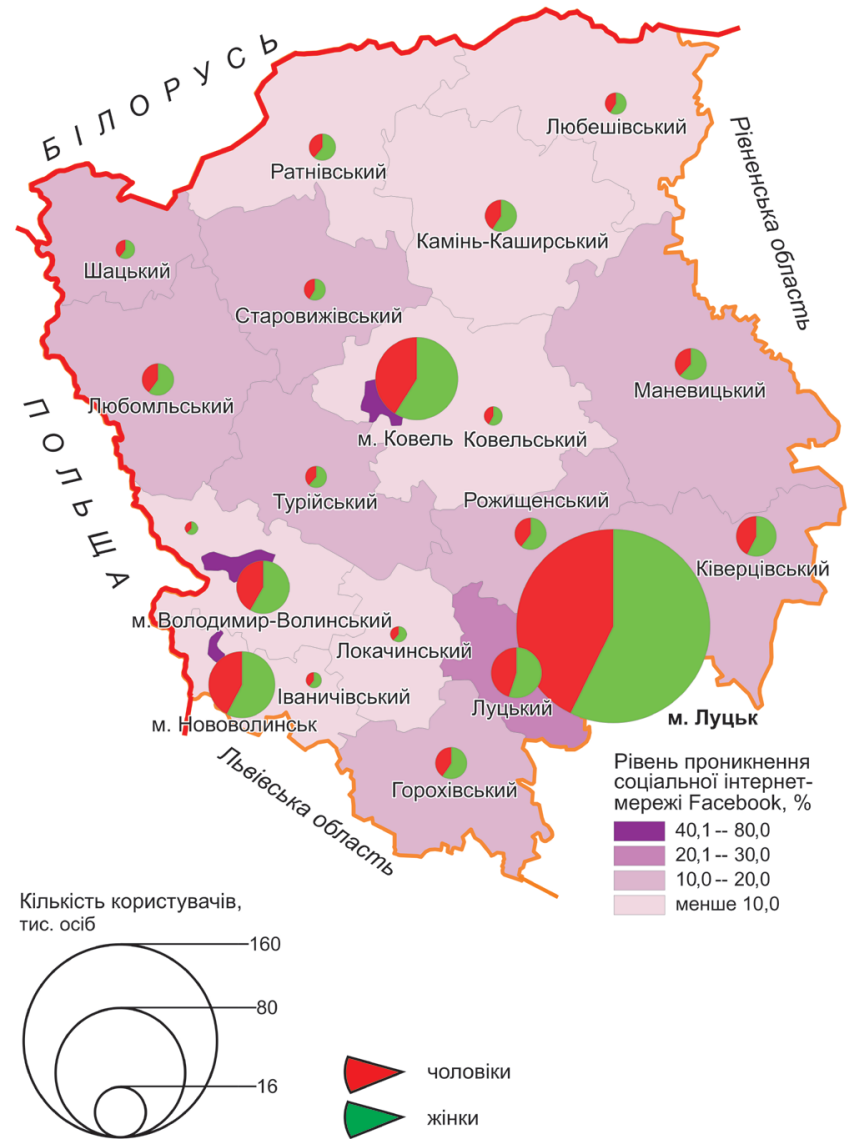

b) Однокласники

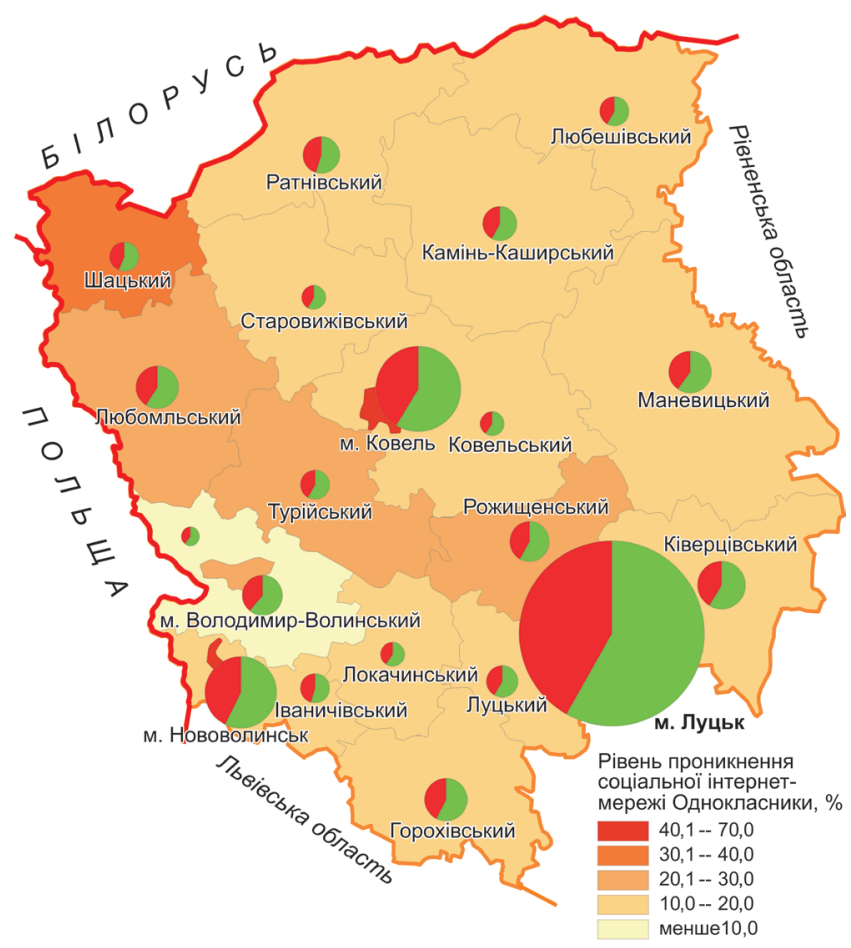

d) Домінуючі соціальні інтернет-мережі

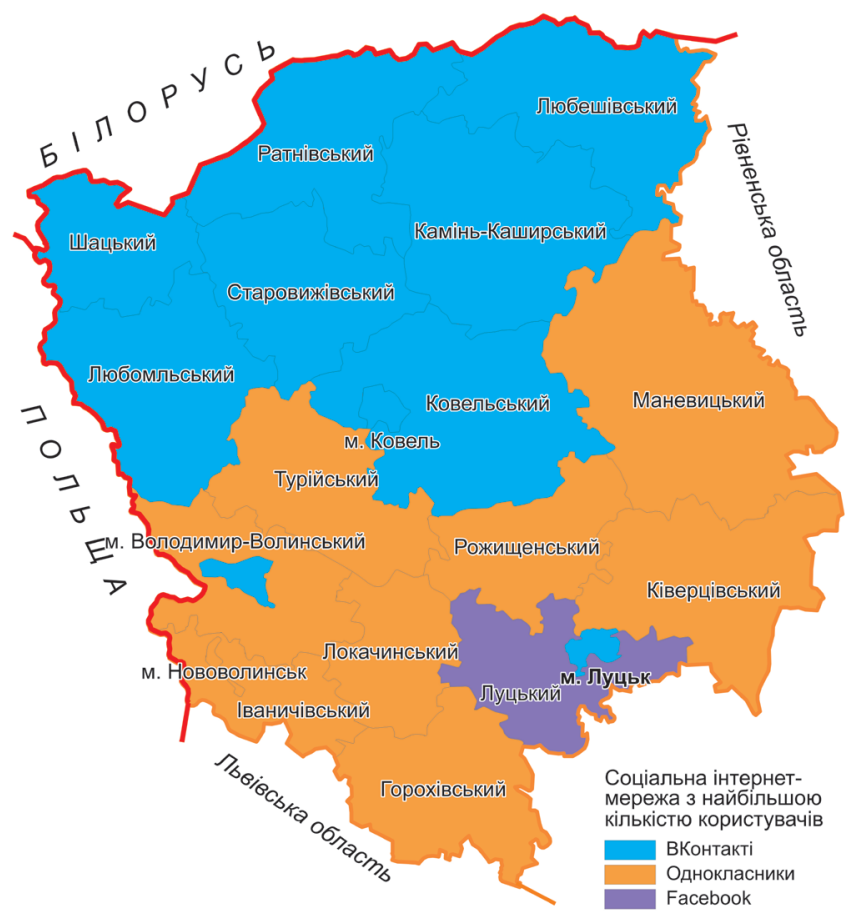

Політико-адміністра-

ивні межі

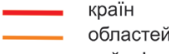

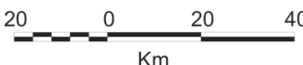

Рис. 1. Територіальна диференціація найбільших соціальних інтернет-мереж у Волинській області (станом на кінець 2017 р.) 
Загалом для населення області це співвідношення складає 52,8 \% та 47,2 \%. Оскільки відомо, що переважання жінок над чоловіками спостерігається у старших вікових групах, то можна зробити висновок, що середній вік користувача соціальної мережі буде нижчим від середнього віку населення Волинської області.

У територіальному аспекті простежується закономірність перевищення чисельності чоловіків над жінками у більшості адміністративнотериторіальних одиниць (рис. 1a). Найвищі показники (понад 52,0 \%) мають Ратнівський, Любешівський, Володимир-Волинський, КаміньКаширський, Старовижівський та Іваничівський райони. Жінки переважають лише у містах обласного підпорядкування. Це знову ж можна пояснити особливостями вікового розподілу користувачів. ВКонтакті позиціонується як «молодіжна» соцмережа, на відміну від Однокласників, яким віддає перевагу «старше» покоління. У сільській місцевості жінки старшого віку не мають надто багато вільного часу для активного користування соціальними мережами. У Любомльському, Локачинському, Ківерцівському районах статевий розподіл $\epsilon$ рівномірним, тобто чоловіки та жінки становлять приблизно однакову частку.

Однокласники - соціальна мережа, російський аналог сайту Classmates.com. Спочатку створений для того, щоб користувачі могли знайти тих, 3 ким вчилися, працювали або дружили, сайт поступово виріс до якісного і повноцінного соціального порталу. Особливістю соціальної мережі Однокласники, є вища частка осіб старшого віку у порівнянні з ВКонтакті.

Станом на кінець 2017 р. в Однокласниках було зареєстровано понад 26,1 млн українців (61,6 \% населення України), 3 них 323,0 тис. користувачів 3 Волинської області, що становить 1,3 \% від усіх українських користувачів [8].

У просторовому аспекті соціальна мережа Однокласники у Волинській області загалом повторює картину, описану для ВКонтакті із певними особливостями. Основна кількість користувачів зосереджена у найбільших містах області. Так, у Луцьку зареєстровано 140,6 тис. користувачів, Ковелі - 35,9 тис., Нововолинську - 25,6 тис., Володимир-Волинському - 9,3 тис. На чотири найбільші міста Волинської області припадає $65,5 \%$ користувачів з Волині, в обласному центрі сконцентровано 43,5\% акаунтів.

Рівень проникнення соціальної мережі (частка населення території, яка зареєстрована у сервісі) в територіальному розподілі має багато рис схожих із поширенням ВКонтакті. Найвища частка населення користується сервісом Однокласники в містах Луцьк, Ковель, Нововолинськ (рис. 1b). Звертає увагу відсутність у цьому переліку четвертого міста обласного підпорядкування Володимир-Волинського $(23,9 \%, 7$ місце в області). Високі показники також характерні для Шацького, Любомльського, Рожищенського та Турійського районів. У випадку Шацького району пояснення можливо у насамперед туристично-рекреаційній спеціалізації, адже для популяризації відпочинку на Шацьких озерах місцеве населення активно використовує різноманітні медіа, у т ч. соціальні інтернет-мережі, як засіб поширення інформації про власний бренд та розміщення оголошень про здачу в оренду житлових приміщень.

Для решти території області характерна відносно низька частка користувачів, що не перевищує $20 \%$, при середньому по області 31,3 \%. Найнижчі показник мають Володимир-Волинський $(9,6$ \%), Ковельський $(10,1 \%)$ та Луцький (10,3 \%) райони. Причини цього ми розглядати при аналізі мережі ВКонтакті населення 3 прилеглих сільських населених пунктів вважає більш престижним вказати своїм місцем проживання великі міста.

Для статевої структури користувачів Однокласники характерним $є$ переважання жінок у всіх адміністративно-територіальних одиницях області. У середньому по Волинській області цей показний становить 58,1%. Що пояснюється як переважанням жінок й серед наявного населення області (52,8 \%), так і вже згадуваною вище популярністю соціальної інтернет-мережі серед населення старшого віку, де диспропорція у статевій структурі більша. Мережа Однокласники на початкових етапах розвитку позиціонувала себе, як сервіс для пошуку давніх друзів (однокласники, одногрупники та ін.), з якими ви в силу тих чи інших причин не підтримуєте (втратили) постійні зв'язки. Саме тому старше покоління, як правило, вибирає Однокласники, не в останню чергу через почуття ностальгії за молодими роками. Молодь, для якої спогади не відіграють такої важливою ролі, вибирає модерні, спрямовані на постійну щоденну комунікацію Facebook та ВКонтакті.

Найвищі показники частки жінок (понад 60 \%) спостерігаються у м. Володимир-Волинський та Володимир-Волинському районі. Причина цьому, можливо, наявність значної частки бувших військових та їх членів їх сімей. У часи СРСР в околицях м. Володимир-Волинський концентрувалося велике угрупування військ. Значна частина військових, які залишилися на постійне проживання не є «місцевими» й активно використовують соціальні мережі для спілкування 3 родичами. Для решти районів Волинської області частка жінок у соціальній мережі Однокласники коливається в межах 54-60 \%.

Facebook - американський соціальний сервіс, спочатку розроблений як засіб для спілкування між студентами американських ВНЗ. Ідея завоювала величезну популярність, зробивши М. Цукерберга одним 3 наймолодших мільярдерів. Facebook $\epsilon$ найбільшою соціальною інтернет-мережею світу, якій віддають перевагу у більшості країн світу. Згідно офіційної статистики, більше 2 млрд людей вже зареєстрували там свої акаунти. Практично кожна велика компанія або фірма, особливо з тих, які виходять на міжнародний ринок, вважає своїм обов'язком завести представництво в Facebook. Якщо говорити про українську аудиторію цієї соціальної мережі, то вона становить 14,0 млн (34,2 \% населення України). Основний приріст користувачів відбувся після набуття чинності Указу Президента України №133/2017 
«Про застосування персональних спеціальних економічних та інших обмежувальних заходів (санкцій)» [14], який в широкому загалі відомий як «Указ про блокування російських сайтів та соцмереж» від 15 травня 2017 р. До цього кількість українських користувачів Facebook не перевищувала 5,6 млн.

Аналізуючи регіональний розподіл користувачів Facebook в Україні, варто зазначити, що у Волинській області зареєстровано 302,4 тис. користувачів [3], що становить 29,1 \% населення області. Частка користувачів із Волинської області складає 2,1% усіх українських користувачів мережі, що є помітно більше, ніж аналогічні показники соціальних мереж ВКонтакті та Однокласники. Це опосередковано вказує на зосередження користувачів ВКонтакті та Однокласники на сході, a Facebook - на заході України.

У територіальному розподілі користувачів Facebook у Волинської області, можна простежити тенденції характерні й для інших соціальних мереж, а саме до концентрації більшості акаунтів у великих містах. Так, у Луцьку зареєстровано близько 150,0 тис. користувачів, Ковелі - 34,0 тис. користувачів, Нововолинську - 23,0 тис. користувачів, ВолодимирВолинському - 16,0 тис. користувачів. На найбільші міста припадає 73,7 \% користувачів з Волині, на м. Луцьк - 49,6 \%. Рівень концентрації мережі Facebook у найбільших містах $є$ вищим ніж у ВКонтакті та Однокласники. Серед адміністративних районів значною чисельністю користувачів відзначаються прилеглі до обласного центру Луцький та Ківерцівський райони. Звідси можна зробити висновок, що населення великих міст швидше змінює російські соціальні мережі на Facebook.

За рівнем проникнення мережі знову ж лідируючі місця займають м. Луцьк (70,1 \%) та інші міста обласного підпорядкування (понад 40 \%). Серед адміністративних районів на першому місці Луцький (21,9%) (рис. 1с). Ця різка відмінність від ВКонтакті та Однокласники пояснюється особливістю методики обчислення кількості акаунтів. Facebook показує реальну кількість користувачів, які постійно перебувають на даній території, а не одну iз граф облікового запису про місце проживання, яке користувач може вказати довільно. Порівняно високі рівні проникнення (понад 15 \%) також мають Любомльський (прикордонний район, населення якого активно здійснює трудові міграції, у т.ч. маятникові), Рожищенський (наявне порівняно велике для Волинської області м. Рожише, зручне транспортногеографічне положення між Луцьком та Ковелем) та Ківерцівський (наявне порівняно велике для Волинської області м. Ківерці, сусідське положення відносно обласного центру).

Для більшості адміністративних районів Волинської області коефіцієнт проникнення соціальної мережі коливається в межах 8-15\%, при середньообласному 29,1 \%. Найнижча частка користувачів (менше 7 \%) зафіксована у Іваничівському, Ковельському та Володимир-Волинському районах. У статевій структурі користувачів соціальної інтернет-мережі Facebook загалом по області спостерігається схожа з Однокласниками картина помітне переважання жінок (57,9 \%). Причини цього пояснюється вище. Окрім того, жінки у порівнянні 3 чоловіками більш схильні до спілкування i, як наслідок, більш активні у соціальних мережах. Найвища частка жінок (понад 60 \%) фіксується у Маневицькому, Володимир-Волинському, Турійському, Локачинському та Ратнівському районах. Найвища частка чоловіків (54,9 \%) i, відповідно, найнижча частка жінок - у Луцькому районі. Певні територіальні закономірності у співвідношенні чоловіків та жінок мережі Facebook у Волинській області не прослідковується. Це, можливо, можна пояснити недосконалістю методики збору даних.

$$
\text { Найбільші соціальні інтернет-мережі }
$$

ВКонтакті, Однокласники та Facebook мають співставні аудиторії на території Волинській області. Найпоширенішою соціальною мережею є ВКонтакті. Вона є найбільшою у 10 адміністративнотериторіальних одиницях області, у тому числі в 3 iз 4 найбільших містах (рис. 1d). У територіальному відношенні це переважно північна частина області. На другому місці, за кількість користувачів, знаходяться Однокласники. Географічно це південна та східна частини області. Соціальна мережа Facebook переважає лише в одній адміністративній одиниці - Луцькому районі. У більшості районів мережа Facebook займає третє місце, друге - у містах Луцьк та Володимир-Волинський.

Висновки та перспективи подальших досліджень. Отже, соціальні інтернет-мережі ВКонтакті, Однокласники та Facebook мають співставні аудиторії у Волинській області. Найпоширенішою соціальною мережею є ВКонтакті, на другому місці знаходяться Одноклассники, на третьому - Facebook. У всіх трьох мережах простежуються схожі територіальні закономірності поширення - 2/3 користувачів зосереджені у чотирьох найбільших містах Луцьк, Ковель, Нововолинськ, Володимир-Волинський. Понад $40 \%$ акаунтів концентрує обласний центр. Чітко простежується теорія просторової дифузії нововведень - найбільші міста виступають центрами інновацій. Коефіцієнт проникнення мережі також є найвищим у найбільших містах. Для більшості адміністративних районів Волинської області коефіцієнт проникнення соціальної мережі становить 10-20 \%, при середньому по області 29-36 \%. Це свідчить про недостатній рівень сформованості мереж та значні перспективи їх розвитку у сільській місцевості. Підвищена частка користувачів ВКонтакті спостерігається у північних прикордонних районах, Facebook - у південних та східних районах, мережа Однокласники має більш рівномірне поширення по території області. У статевій структурі користувачів домінують жінки, особливо це характерно для мережі Однокласники.

Дослідження соціальних мереж сьогодні $є$ надзвичайно актуальним питання, у якому українські географи мало беруть участь. Слід провести дослідження поширення основних мереж на рівні адміністративних районів для інших областей України. Перспективними є дослідження динаміки проникнення соціальних мереж у сільській місцевості. 


\section{References:}

1. Andris C. Integrating social network data into GISystems. International Journal of Geographical Information Science, 2016, Vol. 30 (10), pp. 2009-2031. Doi: 10.1080/13658816.2016.1153103.

2. Borge-Holthoefer J., Rivero A., García I., Cauhé E., Ferrer A., Ferrer D. et al. Structural and dynamical patterns on online social networks: the Spanish May 15th movement as a case study. PloS ONE, 2011, Vol. 6(8), e23883.

3. Facebook [Electronic source]. Access mode: https://www.facebook.com.

4. Glückler J., Doreian P. Editorial: social network analysis and economic geography - positional, evolutionary and multi-level approaches. Journal of Economic Geography, 2016, Vol. 16, Issue 6, pp. 1123-1134.

5. Laniado D., Volkovich Y., Scellato S., Mascolo,C., Kaltenbrunner A. The impact of geographic distance on online social interactions. Information Systems Frontiers, 2017. [Electronic source]. Access mode: http://doi.org/10.1007/ s10796-017-9784-9.

6. Lengyel B., Varga A., Ságvári B., Jakobi Á., Kertész J. Lengyel B. Geographies of an Online Social Network. PLoS ONE, 2015, Vol. 10 (9), e0137248. Doi: 10.1371/journal.pone.0137248.

7. Menezes T., Roth C. Natural Scales in Geographical Patterns. Scientific Reports, 2017, Vol. 7, 45823. Doi:10.1038/ srep45823.

8. Odnoklassniki [Electronic source]. Access mode: https://ok.ru.

9. Oglâd socìal'nih merež ì Tvìttera v Ukraïnì za danimi Pošuku u blogah Ândeksa, 2013-2014 roki [Review of Social Networking Services and Twitter in Ukraine according to Yandex Blog Search, 2013-2014]. [Electronic source]. Access mode: https:/cache-man01i.cdn.yandex.net/download.yandex.ru/company/Yandex_on_UkrainianSMM_ Summer_2014.pdf. (In Ukrainian).

10. Puhach S., Mytchyk Yu. Geografîa poširennâ socìal'nih merež v Ukraïnì [Geography of social networking services in Ukraine]. In: Suspil'no-geografični činniki rozvitku regionìv : materiali Mižnarodnö̈ naukovo-praktičnö̈ Internet-konferencï̈ [Human geographical factors of regional development: materials of the International scientific and practical Internet conference], Eds.: Yu. M. Barskyi, S. O. Puhach, Lutsk, 2017, pp. 99-101. (In Ukrainian).

11. Sui D., Goodchild M. The convergence of GIS and social media: challenges for GIScience. International Journal of Geographical Information Science, 2011, Vol. 25 (11), pp. 1737-1748.

12. Takhteyev Y., Gruzd A., Wellman B. Geography of Twitter networks. Social Networks, 2012, Vol. 34 (1), pp. 73-81. Doi: 10.1016/j.socnet.2011.05.006

13. Ter Wal A., Boschma R. Applying social network analysis in economic geography: framing some key analytic issues. Annals of Regional Science, 2009, Vol. 43, pp. 739-756.

14. Ukaz Prezidenta Ukraïni \#133/2017 "Pro zastosuvannâ personal'nih specìal'nih ekonomičnih ta ìnših obmežuval'nih zahodiv (sankcij)" [Decree of the President of Ukraine No133/2017 "On the Application of Personal Special Economic and Other Restrictive Measures (Sanctions)"]. Administraciâ Prezidenta Ukraïni. Oficìjne internetpredstavnictvo Prezidenta Ukraïni [Administration of the President of Ukraine. Official online representation of the President of Ukraine]. [Electronic source]. Access mode: http://www.president.gov.ua/documents/1332017-21850. (In Ukrainian).

15. Ukraïncìv ne budut' karati za vìdvìduvannâ zaboronenih rosìjs'kih socmerež - RNBO [Ukrainians will not be punished for visiting the banned Russian social networking services - the National Security and Defense Council]. Sajt internet-vidannâ "GORDON" [The website of the Internet publication "GORDON"]. [Electronic source]. Access mode: http://gordonua.com/ukr/news/society/ukrajintsiv-ne-budut-karati-za-vidviduvannja-zaboronenih-rosijskihsotsmerezh-rnbo-188932.html. (In Ukrainian).

16. VKontakte [Electronic source]. Access mode: https://vk.com.

\section{Список використаних джерел:}

1. Andris C. Integrating social network data into GISystems / C. Andris // International Journal of Geographical Information Science. - 2016. - № 30 (10). - P. 2009-2031.

2. Borge-Holthoefer J. Structural and dynamical patterns on online social networks: the Spanish May 15th movement as a case study / J. Borge-Holthoefer, A. Rivero, I. García, E. Cauhé, A. Ferrer, D. Ferrer et.al. // PloS ONE. - 2011. - Vol. 6(8). - e23883.

3. Facebook [Електронний ресурс] : [web-site]. - Режим доступу : https://www.facebook.com. - Haзвa з екрана.

4. Glückler J. Editorial: social network analysis and economic geography - positional, evolutionary and multilevel approaches / J. Glückler, P. Doreian // Journal of Economic Geography. - 2016. - Vol. 16 (6). - P. 1123-1134.

5. Laniado D. The impact of geographic distance on online social interactions / D. Laniado, Y. Volkovich, S. Scellato, C. Mascolo, A. Kaltenbrunner // Information Systems Frontiers, 2017. [Electronic source]. Access mode: http://doi.org/10.1007/s10796-017-9784-9.

6. Lengyel B. Geographies of an Online Social Network / B. Lengyel, A. Varga, B. Ságvári, Á. Jakobi, J. Kertész // PLoS ONE. - 2015. - № 10 (9). - e0137248.

7. Menezes T. Natural Scales in Geographical Patterns / T. Menezes, C. Roth // Scientific Reports. - 2017. - № $7 .-$ P. 45823. 
8. Одноклассники [Електронний ресурс] : [web-site]. - Режим доступу : https://ok.ru. - Назва з екрана.

9. Огляд соціальних мереж і Твіттера в Україні за даними Пошуку у блогах Яндекса, 2013-2014 роки [Електронний ресурс]. - Режим доступу : https://cache-man01i.cdn.yandex.net/download.yandex.ru/company/ Yandex_on_UkrainianSMM_Summer_2014.pdf.

10. Пугач С. Географія поширення соціальних мереж в Україні / С. Пугач, Ю. Митчик // Суспільногеографічні чинники розвитку регіонів : матеріали Міжнар. наук.-практ. Інтернет-конференції / за ред. Ю. М. Барського, С. О. Пугача. - Луцьк : ПП Іванюк В. П., 2017. - С. 99-101.

11. Sui D. The convergence of GIS and social media: challenges for GIScience / D. Sui, M. Goodchild // International Journal of Geographical Information Science. - 2011. - Vol. 25 (11). - P. 1737-1748.

12. Takhteyev Y. Geography of Twitter networks / Y. Takhteyev, A. Gruzd, B. Wellman // Social Networks. - 2012. - № 34 (1). - P. 73-81.

13. Ter Wal A. Applying social network analysis in economic geography: framing some key analytic issues / A. Ter Wal, R. Boschma // Annals of Regional Science. - 2009. - Vol. 43. - P. 739-756.

14. Указ Президента України №133/2017 Про рішення Ради національної безпеки і оборони України від 28 квітня 2017 року «Про застосування персональних спеціальних економічних та інших обмежувальних заходів (санкцій)» [Електронний ресурс] / Адміністрація Президента України. Офіційне інтернет-представництво Президента України [веб-сайт]. - Режим доступу : http://www.president.gov.ua/documents/1332017-21850. - Назва з екрана.

15. Українців не будуть карати за відвідування заборонених російських соцмереж - РНБО [Електронний pecypc] / Інтернет-видання "ГОРДОН" [веб-сайт]. - Режим доступу : http:/gordonua.com/ukr/news/society/ ukrajintsiv-ne-budut-karati-za-vidviduvannja-zaboronenih-rosijskih-sotsmerezh-rnbo-188932.html. - Назва з екрана.

16. ВКонтакті [Електронний ресурс] : [web-site]. - Режим доступу : https://vk.com. - Назва з екрана. 